\title{
TECHNOLOGY PARKS (TP) STRATEGIC CAPACITY EVALUATION STRUCTURE: A FRAMEWORK PROPOSAL FOR IMPLEMENTATION IN LATIN AMERICA
}

\author{
Alandey Severo Leite da Silva \\ Doutorando em Administração de Empresas da Universidade de Fortaleza - UNIFOR \\ Professor da Faculdade Maurício de Nassau - UNINASSAU \\ alandey@gmail.com (Brasil)
}

\section{Sérgio Henrique Arruda Cavalcante Forte}

Doutor em Administração de Empresas pela Fundação Getúlio Vargas - FGV

Professor da Universidade de Fortaleza - UNIFOR

sergioforte@unifor.br (Brasil)

\begin{abstract}
This study relevance contributes an unprecedented manner with a proposal to investigate the strategic capacity evaluation structure of TPs in Latin America. This way, the following research question emerged: how to evaluate the strategic capability of the TPs in Latin America? This study objective is to present a framework proposal for review of the Strategic Capacity of Technological Parks in Latin America. The methodology used in this study is classified, by the objective, as exploratory and the technical procedure used was the literature review. The research approach used was qualitative and quantitative. As a research result, a 4 dimensions ensemble (Infrastructure, Scenarios, Corporate Governance and Strategic Performance) composed of 31 indicators that can corroborate with the TPs in Latin America was identified, after the MACBETH method application with survey data applied to 10 major decision makers of TPs in Latin America.The proposed index can serve as a comparative evaluation between several Latin America TPs. As further research suggestions, are larger exploration of the theoretical references cited and field research framework validation in others continents.
\end{abstract}

Keywords: Technology Parks; Framework; Strategic Capacity. 


\section{INTRODUCTION}

The world is always changing. According to Organization for Economic Co-operation and Development [OECD] (2012) report, the USA, from world major economy representing 23\% of world economic activities, will move to $18 \%$ in 2030 . Euro Zone will move from $17 \%$ to $12 \%$. China, who produces $17 \%$ of world economic activities today, will move to $28 \%$ in 2030 , becoming the major world economy. The Chinese growth and other emerging countries will be led by more skilled and productive labor. India will also be benefit from population growth and its GNP will move from $7 \%$ to $11 \%$ on world economy representation (OECD, 2012).

Traditional organizations are being demolished, companies integrate and mischaracterize, starting to form networks, chains, conglomerates and strategic alliances, the so-called post-Fordist organizations (Clegg \& Hardy, 1999) adapted to the knowledge era, to the unpredictability fast technological and economic transformation conditions (Castell, 1999), like the Technological Parks [TP] (Atuahene-Gima Li, 2004; Lindelöf \& Löfsten, 2002; Townsend et al., 2009).

This study, from the theoretical survey conducted and from survey data applied to 10 major decision makers of TP in Latin America (Brazil, Mexico, Argentina, Colombia, Venezuela, Chile, Uruguay and Peru), consider as proposal capable to contribute to the Latin America TP effectiveness, a framework composed of the Corporate Governance, Scenarios, Infrastructure, Strategic Performance dimensions, generators of needed strategic capability to the TP effectiveness.

In this sense, the article aims to make a first theoretical proposal of a Latin American TP strategic capacity index. As each dimension of this study framework has differentiated importance, it is recommended that the index is weighted and each weight can express the relative importance of each dimension in the final composition proposal.

For dimensions aggregation, it is proposed to use the expertise value judgments of the five largest Latin American TP. To transform the qualitative value judgments in quantitative it is suggested, in a later work, the adoption of MACBETH multi-criteria method (Bana e Costa \& Vansnick, 1995, 1997). The proposed index can serve as a comparative evaluation between Latin Americans TP.

Revista de Administração e Inovação, São Paulo, v. 13, n.1, p.144-165, jan./mar. 2016. 


\section{THEORETICAL APPROACH AND PROPOSALS}

Conceptualizing, TP are innovation environments managed by specialized professionals, whose goal is to increase the wealth and well-being of their community, stimulate the growth of technologybased companies through incubation and spin-offs, and provide other high value added services combined with a physical space and high-quality support services (Anprotec, 2008; Steiner et al., 2015).

Regarding financing, $70 \%$ of $\mathrm{TP}$ in the world receive some form of government subsidy (NBIA, 2014). In Brazil, this percentage approaches 90\% (MCTI, 2013). In Latin America - excluding Brazil - so far, the involvement of the public sector with TP has been relatively scarce. The result is territorially inefficient TP's, unable to promote technological development and knowledge, limited in size due to the low initial levels of investment and little interest from the private sector (Gil-Serrate, 2014; Rodríguez-Pose \& Hardy, 2014).

Bannister and Higgins (1991) and Harrison (1997) relate to strategic capacity only the acquisition of competitive advantage and appropriateness of strategic planning to business objectives. Harrison and Miller (1999) point out that the strategic capacity is the company's condition to overcome all these challenges through effective dissemination of its strategy. For some strategic capacity, usually tied to some more specific factors such as the relationship with stakeholders (Collis \& Rukstad, 2008); learning and organizational knowledge (Wang; Jaw \& Tsai, 2012); the soundness of the strategy through planning and efficient execution (Bannister \& Higgins, 1991; Ismail; Poolton \& Sharifi, 2011; Teece; Pisano \& Schuen, 1997); among others.

An improved and systemic study of TP Strategic Capacity, realized with TPs in Latin America, through proxies Corporate Governance, Scenarios, Infrastructure, Strategic Performance (Figure 1) is required for the challenges highlighted by the necessary harmony between its various actors (stakeholders and shareholders), and also, surveys pointed to a "lack of performance index" appropriate management and evaluation of these institutions (Link \& Siegel, 2003; Phan et al., 2005; Vedovello et al., 1997, p 107; Yim et al. 2011).

In terms of Strategy and Corporate Governance, these issues scientifically emerged in the 1970s when Mace (1971), Norburn and Grinyer (1974) and Pahl and Winkler (1974) adopted theoretical perspectives, for example, the Agency Theory (Daily; Dalton \& Cannella, 2003; Eisenhardt, 1989; Fame \& Jensen, 1983; Hendry \& Kiel, 2004) and the Resource Dependence Theory

Revista de Administração e Inovação, São Paulo, v. 13, n.1, p.144-165, jan./mar. 2016. 
(Carpenter \& Westphal, 2001; Goodstein; Gautam \& Boeker, 1994; Pearce \& Zahra, 1991; Zahra; Pearce, 1989). Thus, the initial proposition (P1) of this research is that:

Proposition 1 (P1): There is an alignment between the Governance and Strategic Capacity.

Regarding Scenarios adoption, the primary interest for it involvement in this study is the fact that they allow detailed exploration of the critical uncertainties of a given system (Martins et al., 2012). A scenario is not a future reality, but rather a means to represent it in order to clarify the present action in the light of possible and desirable futures (Durance \& Godet, 2010).

Taking as an example the innovative and emerging solutions technologically produced within the TP, it is possible that with the ownership of future scenarios these organizations can stay ahead in a controlled manner, to future changes, designing and developing embryonic solutions, but that may be even more profitable to over time. Schoemaker and Mavaddat (2003), argue that emerging technologies are considered to be different from other forms of investment, since small innovations can produce, sometime later, major sectoral changes with social and economic impacts. Scenarios adoption is indispensable to strategy. In this sense, the proposition (P2) of this research is that:

Proposition 2 (P2): There is an alignment between Scenarios and Strategic Capacity.

Regarding Infrastructure adoption as this study construct, Carvalho (2013) points out that since the Egyptian, Chinese and Indian civilizations to contemporary times, many records testify to the strategic action of the infrastructure (hard and soft) in terms of: housing; locomotion; population life quality; way of stimulating economic development; social development improvement factor; interfederative connection instrument; interrelated with the government planning; fiscal adjustment policies protagonist; geopolitical influence tool by foreign countries.

Economist Intelligence Unit [EIU] (2015) report, an entity linked to The Economist, and the Hong Kong and Shanghai Banking Corporation [HSBC], pointed to limited infrastructure as a factor that more negatively influences in the organized ranking by the countries business environment institution.

Wessner (1999) argues that it is essential the TP be provided with a capable and sufficient infrastructure to create opportunities, promote cooperative development, and promote the marketing and attracting of new business. Studies point to the TP infrastructure as a resource and its lack as a barrier to be overcome (SU et al., 2009; Xue, 2007). The infrastructure deficiency, according to Chen and Yu (2008), Phan et al., (2005), Chan and Lau (2005), and Zhou et al., (2011), it is a major obstacle 
to the establishment, growth and development of the potential TP. The infrastructure can be accepted as a strategic resource. Therefore, the third proposition (P3) of this research is that:

Proposition 3 (P3): There is an alignment between the Infrastructure and Strategic Capacity.

Organizational actions mark of efficiency and effectiveness is result in their strategic performance. For this reason, the last dimension adopted as related to strategic capacity of Latin America TP is the strategic performance. According Albahari et al. (2013, pp.601-602), TP performance give up primarily by: (1) TP participation in regional economy; (2) TP impact in innovation generating; and (3) TP impact in regional development. This and other variables were part framework proposed formation. In this horizon, we have the fourth proposition (P4) of this research:

Proposition P4: There is an alignment between the Strategic Performance and Organization Strategic Capacity.

For Miao et al., (2015), Nauwelaers et al., (2014), Rowe (2014), Giugliani (2011) and Zouain (2003), TP, while complex projects and permeated by different actors, which are: i) stakeholders: universities; research institutes; business incubators; technology-based companies - business centers; service centers and coexistence; companies or learning-intensive industries; public sector, at all levels (Federal, State and Municipal); government agencies; developers and investors; business partnerships; banks and / or investors of venture capital and capital; ii) shareholders; lenders or investors; are institutions that need to evolve under review.

Given this gap, after a preliminary theoretical survey, follows Figure 1 with a 4 dimensions framework proposal (Infrastructure, Scenarios, Corporate Governance and Strategic Performance), its 31 indicators that guide the following propositions that can corroborate the evaluation of Latin America TP.

(1) Proposition 1 (P1): There is an alignment between the Governance and Strategic capacity;

(2) Proposition 2 (P2): There is an alignment between Scenarios and Strategic Capacity;

(3) Proposition 3 (P3): There is an alignment between the Infrastructure and Strategic Capacity;

(4) Proposition 4 (P4): There is an alignment between the Strategic Performance and Strategic Capacity. 


\section{TP STRATEGIC CAPACITY THEORETICAL FRAMEWORK PROPOSAL}

Framework is associated to a representation idea of something that wants to be reproduced. A form or pattern capable of having reference function and operate as a prescription for agents who make decisions about practices to be employed in organizations field (Zibolvicius, 1999).

\section{Figure 1: TP Strategic Capacity Index Analysis Framework}

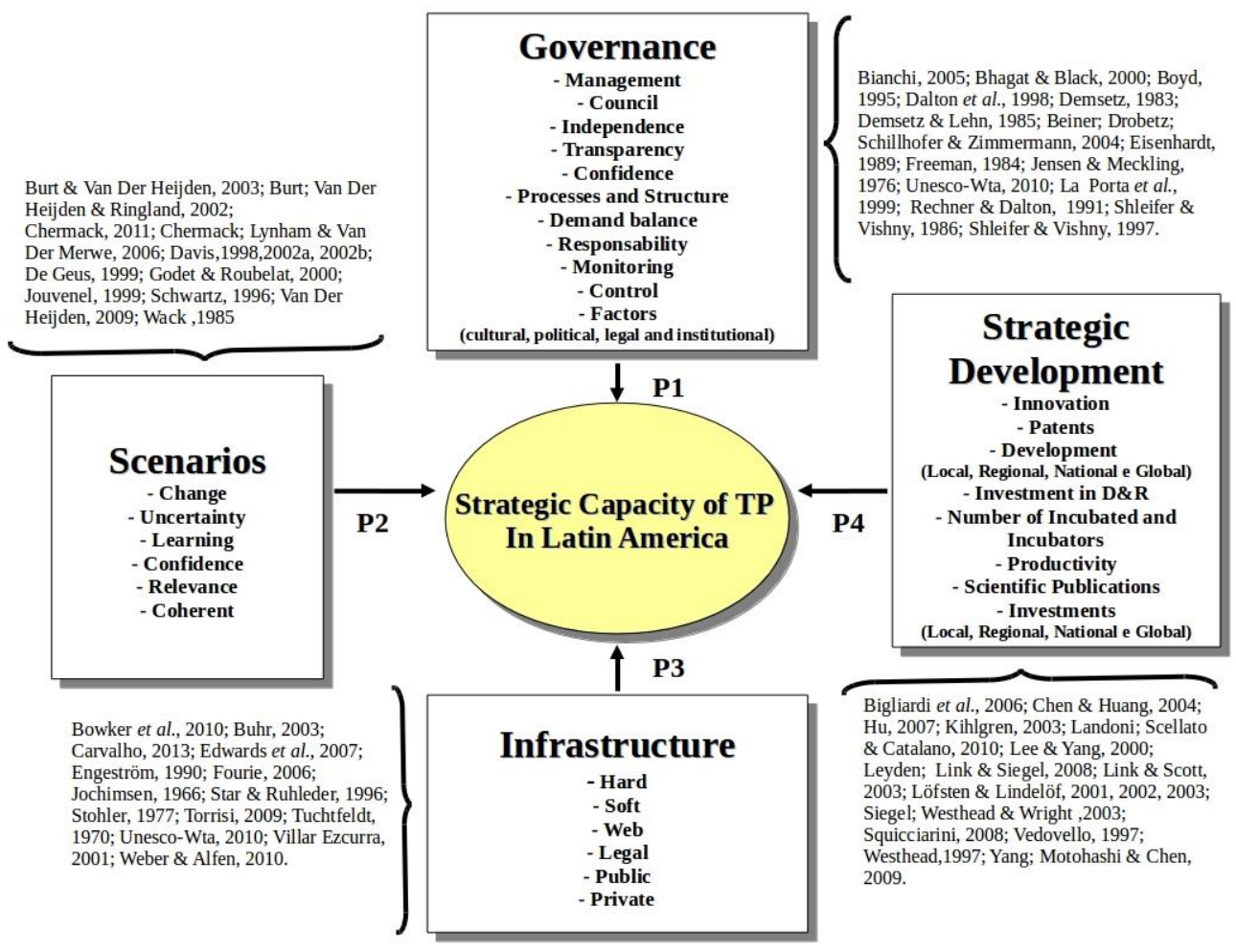

Source: Elaborated by the authors.

Most of the TP researches only address theoretical issues, context, policies, feasibility, regional development, national and international investment and relationships with various stakeholders (Albahari et al., 2013; Bower, 1993; Chan \& Lau 2005; Gainoa et al., 2014; Lee \&Yang, 2000; Lindelof \& Löfsten, 2002; Phan et al., 2005; Wield \& Massey, 1992; Yang et al. 2009), among others, but it is not known studies, indicators or consolidated systemic frameworks involving the strategic capacity.

Despite all plurality, complexity and difficulty of identifying the relevant factors to achieve organizational efficiency and effectiveness of TP, this proposal follows the challenge to meet the strategic capability level of the TP in Latin America through its dimensions and indicators as 
presented. The next section presents a set of methods and techniques to assist or support people and organizations to take action. These funds will be proposed as technology help to consolidate this study framework.

\section{METHODOLOGY}

According to Forte (2006), statistical methods predominate in quantitative research, while categorizations and more essay analysis score in qualitative research. "Anyway, as always, there will be phenomena explanations, calculations and quantitative results, research has itself both methods" (Forte, 2006, p.7). It should be noted that there is no superiority of one type of research over the other on the use of qualitative or quantitative techniques, which depends on the researcher's ability to adapt them to your needs. In Table 1, it is verify a research classification example.

Table 1: Research Classification

\begin{tabular}{|c|c|c|c|}
\hline $\begin{array}{l}1 \text { - As for the Nature of the } \\
\text { Variables }\end{array}$ & Qualitative & \multicolumn{2}{|l|}{ Quantitative } \\
\hline $\begin{array}{l}2 \text { - As for the Goal and the } \\
\text { Problem of Grade }\end{array}$ & Exploratory & Descriptive & Causal \\
\hline 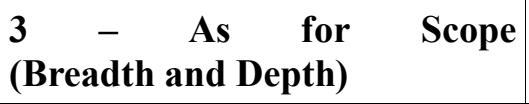 & Case Study & Field Study & $\begin{array}{l}\text { Sample } \\
\text { Survey }\end{array}$ \\
\hline 4-As for Control & Laboratory & \multicolumn{2}{|l|}{ Field Trial } \\
\hline
\end{tabular}

Based on the foregoing, it can be said that through variables nature, this study is classified as a qualitative and quantitative research (Creswell, 2009). The qualitative component, from exploratory character, according to Creswell (2009), aimed to identify the essential factors to assess the strategic capacity through literature, according Marconi and Lakatos (2010), the literature is the literature review that is already published by through electronic consultation on the various bases of national and international data - SI Web of Science; Scopus; ProQuest; CAPES; Academic Search Premier - ASP [EBSCO], ScienceDirect [Elsevier], SpringerLink [MetaPress]. As a complement, the descriptive character quantitative component sought to describe the phenomenon called strategic capacity, sought to explain it by studying the variables, factors and involved criteria, and so suggest their subsequent standardization, validation and definition of a Latin America TP ECI, considering Bana e Costa (1995)

Revista de Administração e Inovação, São Paulo, v. 13, n.1, p.144-165, jan./mar. 2016. 
observations, through MACBETH prescriptive and constructivist approach, and with the help of the Software M-Macbeth (Macbeth, 2015).

Also, interviews with 10 leading decision makers (representatives, directors, superintendents and coordinators) of the main Latin America TP (Brazil, MAXIMUM, Argentina, Colombia, Venezuela, Chile, Uruguay and Peru) were conducted.

\subsection{Framework Proposed Multi-criteria Support Consolidation}

The Multicriteria Decision Support (MDS) is, according to Gomes et al., (2003), a set of methods and techniques to assist or support people and organizations to make decisions when there is the presence of a multiplicity of criteria.

Before applying any multi-criteria analysis method, it is necessary to establish clearly what's the purpose of the analysis, namely what the decision maker wants to achieve when wants to compare each other decision alternatives resorting to using multiple criteria.

We propose in this study through TPs, the subsequent TP framework Strategic Capability Index consolidation through subjective value judgments legitimation and present in all decision making. In TPs, the makers values structure is associated to the existing and used criteria in the alternatives evaluation (Yu, 1985).

For a better explanation, there is Gomes et al. (2004). According to the authors, the steps for multi-criteria analysis decision, involves:

Identify the decision makers and their goals: individuals who make choices and take preference, as a single entity, also called agent or decision maker;

Set the alternative: global actions, which means, actions that can be evaluated in isolation. May represent different courses of action, different assumptions about a feature nature, different sets of features etc;

Identifying the relevant criteria for the decision problem: The criteria are the tools that allow actions comparison in relation to particular views (Roy, 1985). Bouyssou (1990) defines more precisely criterion such as a real-valued function in the set "A" of the alternatives, so that it is meaningful to compare two alternative "a" and "b" in accordance with a particular view, or the qualitative or quantitative expression of a viewpoint is used in the evaluation of alternatives;

Revista de Administração e Inovação, São Paulo, v. 13, n.1, p.144-165, jan./mar. 2016. 
Evaluate alternatives against the criteria: can be divided into a partial actions evaluation phase (alternatives) according to each viewpoint (criteria), and an overall assessment phase considering the various partial assessments. To conduct the evaluation is necessary to choose one of the available methods, traditionally classified into multiattribute problems methods (deal with discrete alternatives) and multi-objective (consider a continuous space of alternatives);

Determine the relative criteria importance: structure and determine the importance attached to one criterion over another, from the adoption of the best methods and functions;

Conduct a comprehensive assessment of each alternative: the overall value of each alternative can be interpreted as a criterion which summarizes the performances by all criteria;

Sensitivity analysis: examining how sensitive the chosen alternative is if the variables involved in the decision model changes. This helps the decision maker to visualize possible paths for any unforeseen situations;

Recommendation: recommend courses of action to be followed;

Implementation: implement the courses of action.

Overall, conventionally up as problems, Structuring Phase is steps 1, 2 and 3. At this stage, it is possible learning and debate mainly by its interactivity, dynamic and common language among decision makers. However, according Bana e Costa et al., (2000), this stage represents about $80 \%$ of the total problem. Steps 4, 5, 6 and 7 make up the Assessment Phase, which aims to apply multicriteria analysis methods to support the modeling of preferences and their aggregation. The third phase, consisting of the steps 8 and 9, is the recommendation phase of the courses of action to be followed. Gomes et al., (2004), regarding step 3, warns that in a complex decision problem, the criteria may be structured as a hierarchy or tree in which the higher level criterion is decomposed into more detailed levels.

How to explain the decision maker's preference structures varies. To consolidate the Latin America TP strategic capacity index recommends a method that can be considered as the American multi-criteria school (Gomes et al., 2004; Pomerol \& Beard-Romero, 2000; Gomes, 1999), mainly because the goal is to construct a single index aggregating by weights means (also called constant scale 
or replacement rates), forming their dimensions. The suggested method is Measuring Attractiveness by a Categorical Based Evaluation Technique [MACBETH].

\subsubsection{Macbeth}

MACBETH, is the method developed by Bana e Costa \& Vansnick $(1995,1997)$ and presented in Bana e Costa et al., (2003, 2004) and Bana e Costa \& Chagas (2004). MACBETH allows aggregating the various evaluation criteria into a single synthesis criterion by assigning weights to various criteria, respecting the decision makers opinions.

Criteria weights are assigned with the alternatives attractiveness pairwise comparison, namely: given two alternatives, the decision maker must say which is the most attractive (must receive the highest score) and what degree this attractiveness has in a semantic scale that has correspondence with an ordinal scale $(0 \equiv$ indifferent, $1 \equiv$ very weak attractiveness difference, $2 \equiv$ weak attractiveness difference, $3 \equiv$ moderate attractiveness difference, $4 \equiv$ strong attractiveness difference, 5 三 very strong attractiveness difference and $6 \equiv$ extreme attractiveness difference).

Through M-Macbeth software (Macbeth, 2015) there is a computer method implementation, carried out the trials analysis consistency and, in case of inconsistency, it is suggested how to resolve it. A rating scale is suggested by linear programming as well as their ranges without making the inconsistent problem (Unfeasible Linear Programming Problem). It is possible to the decision maker adjust the value graphically of allocated grades, within allowable ranges (sensitivity analysis). Only after this adjustment, with the experts knowledge introduction, the value cardinal scale (quantitative) construction is characterized (Bana e Costa \& Ansnick, 1997).

The MACBETH methodology consists of four mathematically linear programming problems (CPPs) sequential: (1) PPL 1 - Problem Mc1: performs the cardinal consistency analysis; (2) PPL 2 Problem Mc2: responsible for building the cardinal value of scale; (3) CPPs 3:04 - Problems Mc3 and MC4: reveal inconsistency sources.

Operationally, Bana e Costa \& Vansnick (1995) propose the construction of judgments arrays to facilitate the expression of absolute judgments of attractiveness between pairs of stocks difference. Each $X_{i j}$ element of the array takes the value $\mathrm{k}(\mathrm{k}=1,2,3,4,5,6)$ if the decision maker decides that the pair's attractiveness difference $\left(a_{i}, a_{j}\right)$ belongs to the class $\mathrm{C}_{\mathrm{k}}$. These numbers have no mathematical meaning; only serve as semantic indicators which category of attractiveness difference was attributed to the respective pair.

Revista de Administração e Inovação, São Paulo, v. 13, n.1, p.144-165, jan./mar. 2016. 
From the foregoing, it executes MACBETH methodology, initially for any inconsistencies checking and then determining a cardinal scale value representing the decision maker's judgment value (expertise). The obtained scale is normalized, providing the evaluation alternatives weight values, which allows the use of an aggregation model generally additive.

\section{DISCUSSION AND RESULTS}

Latin America has a lot to do in terms of Regional Innovation System. With regard to TP, after Brazil, the first unit in Latin America emerged in Colombia (Antioquia) and dates back to 1998. Just to give an example, in a country with Peru's dimensions, the TP still's walk in the consolidation process.

This study results shows that in Latin America the TP development policies are far from reaching their objectives with little impact initiatives in terms of TP. It should be noted, however, that in less than 20 years the TP total went from almost nothing to about 170 parks in different stages of development (operation, execution or planned) in Latin America. Most TP began their operation after 2000 (Agapitova et al., 2002; Gil-Serrate, 2014; Llisterri et al., 2011; Rodríguez-Pose \& Hardy, 2014).

Since this is an index construction proposal, the result is the own Framework (shown in Figure 1) and the MACBETH method application proposed as further consolidation activity.

Compared to Macbeth, it is noteworthy, as presented, a special attention to the modeling phases for effective content validation. The first stage of a multi-criteria modeling is the structure phase, composed of three stages. At 1st step will be identified the decision-makers and their objectives. It is suggested as decision maker the TP expertise (board member, manager etc) to issue judgments about the difference in attractiveness between the evaluated dimensions. The aim of the decision maker is to generate a single output index that adds the generating dimensions of Latin America TP Strategic Capacity. At this stage the actions to be evaluated are identified. This actions family should be a coherent family, that is, must be cohesive, not redundant and exhaustive. From phase 2, the MACBETH multi-criteria method will support the preferences modeling and appropriate mergers.

The aspects considered more important to the development of the framework proposal for review of the Strategic Capacity of Technological Parks in Latin America are better visualized with the structure in "tree of values", where the points of view that interest in the evaluations of what is sought will reflect on the decision-making in every situation, by using the options to achieve the purpose (Bana e Costa et al., 2015).

Revista de Administração e Inovação, São Paulo, v. 13, n.1, p.144-165, jan./mar. 2016. 
The options used in the model were the 10 TP represented in the survey. Of the 31 indicators used as "criteria nodes", the Governance factor nodes had the highest weights (between 3.28 and 5.0). Scenario factor nodes had the second best weights (2.41 to 3.10), followed by the Infrastructure factor nodes weighing between 1.04 and 2.24. Finally, Strategic Performance factor nodes had the lowest weights (0.17 to 1.22$)$.

The calculated results show that the overall score of the TP options from Brazil, Argentina and Chile had overall scores in the range of 80.0.

The positioning in terms of contribution and feasibility for each option and criteria lead to classify them as: (1) practices with high input and high feasibility; (2) practices with high contribution and hard to feasibility, but in case of elimination of implementation difficulties could become references; (3) low contribution practices, but easy to implement. In some contexts these practices should not be discarded because they could be complemented with other practices to obtain benefits in the short term; and (4) rare practices that have low contribution and require more attention to implementation.

By using sensitivity, interactivity and robustness analyzes it can decide and recommend as priority practices with greater contribution and work towards creating the necessary conditions for the implementation / feasibility of the practices that proved to be a lesser share. Through this analysis, the "Management" criteria, "Council" and "Independence" were selected by most decision makers of all options (10 TP).

\section{CONCLUSION}

This article presents a first approach to study the relative importance of Latin America TP Strategic Capacity forming dimensions, with the possible support models of Operations Research, namely, models Multicriteria Decision Support, in order to generate a TP strategic capacity index. From the literature developed along this research, it was theoretically possible to propose Latin America TP Strategic Capacity Index Analysis Framework that, after MACBETH method application, represented an effective measure of comparison. The survey represents a contribution towards interrelate the use of strategic capacity indicators within the TP with Corporate Governance, Scenarios, Infrastructure and Strategic Performance.

Revista de Administração e Inovação, São Paulo, v. 13, n.1, p.144-165, jan./mar. 2016. 
After the questionnaires and analysis of results obtained through the options studied, it was evidenced, by the overall score obtained by Latin Americans TP considered in the study, that if the TP get an average (score) over than 80 points, it can be considered that it presents strategic capacity to be economically sustainable, socially and environmentally. In the case where the score is below this average, it is necessary plans for deficit practices can be remedied and that this TP has a differentiated strategic capacity. Brazil, Argentina and Chile were the geographic areas of reference in developing all aspects.

It appears that if the representatives, directors, superintendents and coordinators of TP in Latin America do not get a good performance on the criteria and factors considered in the model created in this study, in which they considered the characteristics and skills essential to the strategic capacity of Latin Americans TP's and their respective criteria, the projects under their responsibility are less likely to be successful and sustainable, because the better grades options (above 80 points performance) were precisely the TP respondents who have shown good results.

However, it is believed that there is still much to be towards this end. As further research suggestions, are applying MACBETH method in the proposed index consolidation, further exploration of cited theoretical references, as well test content on fieldwork.

\section{REFERENCES}

Agapitova, N., Holm-Nielsen, L., \& Vukmirovic, O. G. (2002). The evolution of science \& technology: Latin America and the Caribbean in comparative perspective. World Bank; Latin America and the Caribbean Regional Office.

Albahari, Alberto, Catalano, Giuseppe \& Landoni, Paolo. (2013). Evaluation of national science park systems: a theoretical framework and its application to the Italian and Spanish systems. Technology Analysis \& Strategic Management, 25 (5), (pp.599-614).

Associação Nacional de Entidades Promotoras de Empreendimentos Inovadores (ANPROTEC). (2008). Portfolio dos Parques Tecnológicos brasileiros. December.

Bana e Costa C.A. \& Chagas, M.P. (2004). A career choice problem: an example of how to use macbeth to build a quantitative value model based on qualitative value judgments. European Journal of Operational Research, 153 (2), (pp.323-331).

Bana e Costa, C.A., De Corte, Jean-Marie \& Vansnick, Jean-Claude. (2015). M- Macbeth Versão

Revista de Administração e Inovação, São Paulo, v. 13, n.1, p.144-165, jan./mar. 2016. 
3.0, guia do utilizador/manual do usuário. (Jan./2015). Available <HTTP//www.MMACBETH.com>. Access in: 19 jun. 2015.

Bana e Costa, C.A. \& Vansnick, J.C. (1995). Uma nova abordagem ao problema da construção de uma função de valor cardinal: MACBETH. Investigação Operacional, 15, (pp.15-35).

Bana e Costa, C.A. \& Vansnick, J.C. (1997).Thoughts on a theoretical framework for measuring attractiveness by categorical based evaluation technique (MACBETH). In: CLÍMACO, J. (Ed.) Multicriteria Analysis, Berlin: Springer-Verlag.

Bana e Costa, C.A., De Corte, J.M. \& Vansnick, J.C. (2003). MACBETH. Working Paper LSEOR 03.56. London: London School of Economics.

Bana e Costa, C.A., De Corte, J.M. \& Vansnick, J.C. (2004). On the Mathematical Foundations of Macbeth. Working Paper LSEOR 03.61. London: London School of Economics.

Bannister, B. D. \& Higgins, R. B. (1991). Strategic Capability, Corporate Communications and Strategic Credibility. Academy of Management Proceedings, (pp. 2-6), Aug.

Beiner, S., Drobetz, W., Schimd, Markus \& Zimmermann, Heinz. (2004). An Integrated framework of corporate governance and firm valuation - Evidence from Switzerland. ECGI finance working paper series, p.34.

Bhagat, S. \& Black, B. (2000). Board independence and long term firm performance. Working Paper, 143. Columbia, Columbia Law School, p.41.

Bianchi, M. A. (2005). Controladoria como um mecanismo interno de governança corporativa e de redução dos conflitos de interesse entre principal e agente. 2005, $158 \mathrm{f}$. Dissertação (Mestrado em Ciências Contábeis)-Universidade do Vale do Rio dos Sinos, São Leopoldo: UNISINOS.

Bigliardi, B., A.I. Dormio; Nosella, A. \& Petroni, G. (2006)Assessing science parks' performances: Directions from selected Italian case studies. Technovation, 26, (pp.489-505).

Bouyssou, B. Building criteria: a prerequisite for MCDA. (1990). In: Bana e Costa C.A. (Eds.). Readings in Multiple Criteria Decision Aid, p. 58-80.

Bower, D. Jarze. Successful Joint Ventures in Science Parks.(1993). Long Range Planning, 26(6), (pp.114-120).

Bowker, G. C, Baker K; Millerand F \& Ribes D. (2010). Toward information infrastructure studies: ways of knowing in a networked environment. In: Hunsinger, J, Klastrup L, Allen, M (Eds.). International handbook of internet research. Dordrecht: Springer, (pp. 97-117).

Boyd, B. K. CEO Duality and Firm Performance: A contingency model. (1995). Strategic 
Management Journal, 16 (4), (pp. 301-312).

Buhr, Walter. What is infrastructure?(2003).Volkswirtschaftliche Diskussionsbeiträge. 107.

Burt, G. \& van der Heijden, K. Futures 35. (2003). Elsevier Science and Hines A, An Audit for Organisational Futurists. Foresight 5.1.

Burt, G., van der Heijden, K. \& Ringland, J. (Ed.) (2002). Reframing industry boundaries for structural advantage; the role of scenario planning. In: Scenarios in Business, United Kingdom, (pp. 223-232).

Carpenter, M. A. \& Westphal, J. D.(2001). The Strategic Context of External Network Ties: Examining the Impact of Director Appointments on Board Involvement in Strategic Decision Making. Academy of Management Journal, 4(4), (pp. 639-660), Aug.

Carvalho, André Castro. Infraestrutura sob uma perspectiva pública: instrumentos para o seu desenvolvimento. (2013). Tese de Doutorado. Faculdade de Direito da Universidade de São Paulo.

Castells, M. (1999). A. sociedade em rede a era da informação: economia, sociedade e cultura. São Paulo: Paz e Terra.

Chan, K.F. \& Lau, T. (2005). Assessing technology incubator programs in the science park: the good, the bad and the ugly. Technovation. 25(10), (pp.1215-1228).

Chen, C.-T., Chien , C.-F., Lin, M.-H. \& Wang, J.-T. (2004).Using DEA to evaluate R\&D performance of the computers and peripherals firms in Taiwan. International Journal of Business. 9(4).

Chen, Hsiao-Chi \& Yu, Ya-Wen. (2008). Using a strategic approach to analysis the location selection for high-tech firms in Taiwan. Management Research News. 31(4), (pp. 228-244).

Chermack, T. J. (2011). Scenario Planning in Organizations. San Francisco (CA): BerrettKoehler Plublishers, Inc.

Chermack, T. J., Lynham, S. A. \&Van Der Merwe, L. (2006). Exploring the relationship between scenario planning and perceptions of learning organization characteristics. Futures, 38 (7), (pp. 767-777), Sep.

Creswell, J. W. (2009). Research design: qualitative, quantitative, and mixed methods approaches. Thousand Oaks: Sage Publications.

Daily, C., Dalton, D. \& Cannella, A. (2003). Corporate governance: decades of 
dialogue and data. Academy of Management Review, 28(3), (pp. 371-382).

Dalton, D. R., Daily, C. M., Ellstrand, A. E. \& Johnson, J. L. (1998). Meta-analytic reviews of board composition, leadership structure, and financial performance. Strategic Management Journal, 19(3), (pp. 269-290).

Davis, G. (1998). Creating Scenarios for Your Company's Future. Shell International, The 1998 Conference on Corporate Environmental, Health, and Safety Excellence - Bringing Sustainable Development Down to Earth. New York/NY..

Davis, G. (2002a). Questioning Assumptions - Exploring Alternative Business Futures, Swedbank Conference, Stockolm.

Davis, G. (2002b). Scenarios as Tool for the 21st Century - Probing the Future Conference,Strathclyde University, Glasgow, Scotland.

De Geus, A. (1999). The living company: Growth, learning and longevity. Boston: Harvard Business School Press.

Demsetz, H. \& Lehn, K. (1985) The structure of corporate ownership: Causes and consequences. Journal of Political Economy, 93(6), (pp. 1155-1177), Dec.

Durance, P. \& Godet, M. (2010). Scenario building: Uses and abuses. Technological Forecasting and Social Change, 77(9),(pp.1488-1492).

Edwards, P. N., Jackson, S. J., Bowker, G. C. \& Knobel, C. P. (2007). Understanding Infrastructure: Dynamics, Tensions, and Design. Ann Arbor: DeepBlue.

Eisenhardt, K. M. (1989). Agency Theory: An Assessment and Review. Academy of Management Review, 14(1),(pp. 57-74).

Eisenhardt, K.M. (1989). Agency theory: an assessment and review', Academy of Management Review. 14(1), (pp.57-74).

Engeström, Yrjo. When Is a Tool? (1990). Multiple Meanings of Artifacts in Human Activity. In: Working and Imagining. Orienta-Konsultit Oy, Helsinki.

Fama, E. F. \& Jensen, M. C. (1983). Separation of Ownership and Control. Journal of Law and Economics. 26 (2), (pp. 301-325) Jun.

Fourie, Johan. (2006). Economic infrastructure: a review of definitions, theory and empirics. South African Journal of Economics. 74 (3), (pp. 530-556). Sept. 
Freeman, R. E.(1984). Strategic management: a stakeholder approach. Boston: Pitman.

Gainoa, Alexandre Augusto Pereira \& Pamplona, João Batista. (2014). Abordagem teórica dos condicionantes da formação e consolidação dos parques tecnológicos. Production. 24 (1), (pp. 177-187).

Gil-Serrate, Ramiro. (2014). Los Parques Científicos y Tecnológicos en América Latina: análisis de la situación actual. CENTRUM Católica - Pontificia Universidad Católica del Perú.

Godet, Michael \& Roubelat, Fabrice. (2000). Scenario Planning: An Open Future, Technological Forecasting and Social Change. New York: Elsevier Science Inc.

Gomes, E.G. Integração entre Sistemas de Informação Geográfica e Métodos Multicritério no Apoio à Decisão Espacial. 1999. Tese (Mestrado em Engenharia de Produção) - COPPE, Universidade Federal do Rio de Janeiro, Rio de Janeiro.

Gomes, E.G., Leta, F. R. \& Pessolani, R.B.V. (2003). Conceitos básicos do Apoio Multicritério à Decisão e sua aplicação no Projeto Aerodesign. Engevista, 5 (8),(pp. 22-35).

Gomes, L.F.A.M., Gonzalez- Araya, M.C. \& Carignano, C. (2004). Tomada de decisões em cenários complexos. São Paulo: Pioneira Thompson Learning.

Goodstein, J., Gautam, K. \& Boeker, W. (1994).The Effects of Board Size and Diversity on Strategic Change. Strategic Management Journal, 15(3), (pp. 241-250), Mar.

Hendry, K., Kiel, G. C. (2004). The Role of the Board in Firm Strategy: integrating agency and organisational control perspectives. Corporate Governance, 12(4), (pp. 500-520).

Hu, A.G.Z. (2007).Technology parks and regional economic growth in China.Research Policy, 36, (pp.76-87).

Ismail, H. S., Poolton, J. \& Sharifi, H. (2011). The role of agile strategic capabilities in achieving resilience in manufacturing-based small companies. International Journal of Production Research, 49(18), (pp. 5469-5487), sept.

Jensen, M. C. \& Meckling, W. H. (1976). Theory of the Firm: managerial behavior, agency costs and ownership structure. Journal of Financial Economics, 3(4), (pp. 305-360).

Jochimsen, R. (1966). Theorie der Infrastruktur, Grundlagen der marktwirtschaftlichen Entwicklung. Tübingen (J. C. B. Mohr (Paul Siebeck)).

Jouvenel, Hughes. (1999). Démarches prospectives. Revue Futuribles, 247, Nov.

Revista de Administração e Inovação, São Paulo, v. 13, n.1, p.144-165, jan./mar. 2016. 
Kihlgren, A. (2003). Promotion of innovation activity in Russia through the creation of science parks: The case of St. Petersburg (1992-1998). Technovation. 23, (pp.65-76).

La Porta, R., Lopez-De-Silanes, F. \& Shleifer, A. (1999). Corporate ownership around the world. The Journal of Finance, 54 (2), (pp. 471-517), Apr.

Lakatos, E. M. \& Marconi, M. A. (2010). Técnicas de pesquisa. São Paulo:Atlas, 7a edição.

Landoni, P., Scellato, G. \& Catalano, G. (2010). Science parks contribution to scientific and technological local development: The case of AREA Science Park Trieste. International Journal of Technology, Policy and Management, 10,(pp.36-52).

Lee, W.H \& Yang, W.T. (2000). The cradle of Taiwan high technology industry development Hsinchu Science Park (HSP). Technovation. 20, (pp.55-59).

Lee, W.H \& Yang, W.T. (2000).The cradle of Taiwan high technology industry development Hsinchu Science Park (HSP). Technovation. 20, (pp.55-59).

Leyden, D., Link, A.N. \& Siegel, D.S. (2008). A theoretical and empirical analysis of the decision to locate on a university research park. IEEE Transactions on Engineering Management. 5, (pp.23-28).

Lindelöf, P. \& Löfsten, H. (2002). Growth, management and financing of new technology-based firms-assessing value added contributions of firms located on and off science parks. Omega-The International Journal of Management Science. 30(3), (pp.143-54).

Link , A.N. \& Scott , J.T. (2003). Science parks and the generation of university-based knowledge: an exploratory study. International Journal of Industrial Organization, 21(9), (pp. 1323-1356).

Löfsten, H. \& P. Lindelöf. (2001). Science parks in Sweden - industrial renewal and development? R\&D Management. 31, (pp. 309-22).

Löfsten, H. \& P. Lindelöf. (2002). Science parks and the growth of newtechnology-based firmsacademic-industry links, innovation and markets. Research Policy. 31, (pp.859-76).

Löfsten, H. \& P. Lindelöf. (2003). Determinants for an entrepreneurial milieu: Science parks and business policy in growing firms. Technovation. 23, (pp. 51-64).

Llisterri, J. J., \& Pietrobelli, C. (2011). Los sistemas regionales de innovación en América Latina. Banco Interamericano de Desarrollo.

Mace, M. L. G. (1971). Directors:Myth and Reality. Boston: Division of Research Graduate 
School of Business Administration. Harvard University.

Martins, P. P. P., Boaventura, J. M. G., Spers, R. G., Fischmann, A. A. \& Costa, B. K. (2012). Scenarios for the Brazilian Road Freight Transport Industry. Foresight, 14(3), (pp.81-100).

MINISTÉRIO DA CIÊNCIA, TECNOLOGIA E INOVAÇÃO (MCTI). (2013). Estudo de projeto de alta complexidade: indicadores de parques tecnológicos - versão resumida. Brasília: MCTI.

National Business Incubation Association (NBIA). Financing (2014).

Norburn, D. \& Grinyer, P. H. (1974). Directors Without Direction. Journal of General

Management, 2(2), (pp.37-48).

Organisation for Economic Cooperation And Development (OECD). (2012). Looking to 2060: A Global Vision of Long-Term Growth, OECD Economics Department Policy Notes, No. 15. November.

Pahl, R. E., Winkler, J. T. (1974). The Economic Elite: Theory and Practice. In: Stanworth, P. \& A. Giddens, A. (Eds). Elites and Power in British Society. London: Cambridge University Press.

Pearce, J. A. \& Zahra, S. A. (1991). The Relative Power of CEOs and Boards of Directors: Associations with Corporate Performance. Strategic Management Journal, 12(2), (pp. 135-153), Feb.

Phan, P.H., Siegel, D.S. \& Wright, M. (2005). Science parks and incubators: observations, synthesis and future research. Journal of Business Venturing. 20(2), (pp.165-182).

Pomerol, J.C. \& Barba-Romero, S. (2000). Multicriterion Decision in Management: Principles and Practice. Boston: Kluwer Academic Publishers.

Rechner, P. L. \& Dalton, D. R. (1991). CEO duality and organizational performance: A longitudinal analysis. Strategic Management Journal, 12(2), (pp. 155-160).

Rodríguez-Pose, Andrés \& HARDY, Daniel. (2014). Technology and Industrial Parks in Emerging Countries: Panacea Or Pipedream?. Springer.

Roy, B. (1985). Méthodologie multicritère d'aide à la décision. Economica, Paris.

Schoemaker, Paul J. H. \& Mavaddat, V. Michael. (2003). Planejamento de Cenários para Tecnologias Revolucionárias. In: Day, G. S., Schoemaker, Paul. J. H. \& Gunther, R. E. (Eds.). Gestão de Tecnologias Emergentes: a visão da Wharton School. 1. ed. São Paulo: Bookman, (pp. 
187-214).

Schwartz, P. (1996). The Art of the Long View. Planning for the Future in an Uncertain World. New York: Doubleday Publishing.

Shleifer, A. \& Vishny, R. (1986). Large Shareholders and Corporate Control. Journal of Political Economy, 94(3), (pp. 461-468), Jun.

Shleifer,A. \& Vishny,R. (1997). A Survey of Corporate Governance. Journal of Finance, 2(2), (pp.737 783).

Siegel, D.S., Westhead, P. \& Wright, (2003). M. Science parks and the performance of new technology-based firms: A review of recent U.K. evidence and an agenda for future research. Small Business Economics. 20, (pp.177-84).

Star, S. L. \& Ruhleder, K. (1996). Steps toward an ecology of infrastructure: Design and access for large information spaces. Information Systems Research. 7(1), (pp.111-134).

Steiner, João E., Cassim, Marisa Barbar \& Robazzi, Antonio Carlos. Parques Tecnológicos: Ambientes de Inovação. Available in: < http://www.iea.usp.br/>.

Stohler, Jacques. (1977). Zur rationale Planung der Infrastruktur. In: Simonis, Udo Ernst (Hrsg.). Infrastruktur: Theorie und Politik. Köln: Kiepenheuer \& Witsch, (pp. 16-37).

SU, J., HE, J.Q., XUE, E.Y., XIAO, Y.D., LI, S.C., SUI, J.G., XIE, X. \& ZHOU, Y. (2009). A Study of Knowledge-based Innovation and Technology Spin-offs in Chinese University. Tsinghua University Press, Beijing.

Teece, D.J., Pisano, G. \& Shuen, A. (1997). Dynamic Capabilities and Strategic Management. Strategic Management Journal, 18(7), (pp. 509-533).

Torrisi, Gianpiero. (2009). Public infrastructure: definition, classification and measurement issues. Munich Personal RePEc Archive. n. 12990. München: MPRA. Available in: <http://mpra.ub.uni-muenchen.de/12990/1/MPRA_paper_12990.pdf>.

Townsend, A.M., Soojung-Kim Pang, A. \& WEDDLE, R. (2009). Future Knowledge Ecosystems: The Next Twenty Years of Technology-Led Economic Development. Institute for the Future: Palo Alto, California.

Tuchtfeldt, Egon. (1970). Infrastrukturinvestitionen als Mittel der Strukturpolitik. In: Jochimsen, Reimut, Simonis, Udo Ernst. Theorie und Praxis der Infrastrukturpolitik. Berlin: Duncker \& Humblot, (pp. 125-151).

Unesco-Wta. (2010). Science Park and Technology Business Incubator. Initiatives (2006-2010), United Nations Educational, Scientific and Cultural Organization (UNESCO) and the World 
Technopolis. Association (WTA). Paris and Daejeon.

Van Der Heijden,K. (1996). Scenarios:The Art of Strategic Conversation.Chichester:John Wiley $\&$ Sons.

Vedovello, C. (1997). Science parks and university-industry interaction: Geographical proximity between the agents as a driving force. Technovation. 17, (pp.491-502).

Villar Ezcurra, José Luis. (2001). Las infraestructuras públicas: viejos y nuevos planteamientos. In: ARIÑO \& ALMOGUERA, ABOGADOS (Ed.). Nuevo derecho de las infraestructuras. Madrid: Montecorvo, (pp. 69-118).

Wack, P. (1985). Scenarios: Uncharted waters ahead. Harvard Business Review, 63(5), (pp. 7289).

Weber, Barbara \& Alfen, Hans Wilhelm. (2010). Infrastructure as an asset class: investment strategies, project finance and PPP. West Sussex: John Wiley \& Sons.

WESSNER, Charles W. (1999). National Research Council, Industry-Laboratory Partnerships: A Review of the Sandia Science and Technology Park Initiative. Washington, DC: National Academy Press.

Westhead,P. \& Batstone, S. (1998). Independent technology-based firms:Theperceived benefits of a science park location. Urban Studies, 35, (pp.2197-219).

Wield, David \& Massey, Doreen. (1992). Academic-industry links and innovation: questioning the science park model. Technovation. 12(3), (pp.161 - 175).

Xue, L. (2007). The changing roles of universities in China's national innovation system. Paper presented at Biennial International Conference on University, Industry and Government Linkages, Paris.

Yang, Chih-Hai, Motohashi, Kazuyuki \& Chen, Jong-Rong. (2009). Are new technology-based firms located on science parks really more innovative? Evidence from Taiwan. Research Policy. 38, (pp.77-85).

Yim, D.S., Seong, Y.C., Lee, W.I., PARK, S. \& HONG, J.K. (2011). Management and governance issues in the development of Science and Technology based Innovation Cluster. PICMET: Portland International Center for Management of Engineering and Technology.

Yu, P.L. (1985). Multiple criteria decision making: concepts, techniques and extensions. New York: Plenum Press. 
Zahra, S. A., Pearce, J. A. (1989). Boards of directors and corporate financial performance: a review and integrative model. Journal of Management. 15(2), (p. 291).

Zhou, Y, Xu, G. ,SU, Jun \& Minshall, T. (2011). Barriers to entrepreneurial growth: an empirical study on university spin-offs in China. Journal of Science and Technology Policy in China,2(3), (pp. 277-294).

Zibolvicius, M. (1999). Modelos para a produção, produção para os modelos: gênese, lógica e difusão do modelo japonês nas organizações de produção. São Paulo: FAPESP.

Albahari, Alberto, Catalano, Giuseppe \& Landoni, Paolo. (2013). Evaluation of national science park systems: a theoretical framework and its application to the Italian and Spanish systems. Technology Analysis \& Strategic Management, 25 (5), (pp.599-614).

Associação Nacional de Entidades Promotoras de Empreendimentos Inovadores (ANPROTEC). (2008). Portfolio dos Parques Tecnológicos brasileiros. December.

Bana e Costa C.A. \& Chagas, M.P. (2004). A career choice problem: an example of how to use macbeth to build a quantitative value model based on qualitative value judgments. European Journal of Operational Research, 153 (2), (pp.323-331).

The date of receipt: 10/23/2015

The date of acceptance: 01/28/2016

Revista de Administração e Inovação, São Paulo, v. 13, n.1, p.144-165, jan./mar. 2016. 